\title{
Abnormal biochemical parameters among term neonates with perinatal asphyxia and their non-asphyxiated controls in Osogbo.
}

\author{
*Kayode, O.V. ${ }^{1}$, Adebami, O.J. ${ }^{2}$, Oyedeji, O.A. ${ }^{2}$, Oninla, S. O. ${ }^{2}$, Oseni, S.B.A. ${ }^{3}$, \\ Odeyemi, A.O. ${ }^{4}$
}

\begin{abstract}
Objective: This study aimed to determine the prevalence of abnormal biochemical parameters among neonates with perinatal asphyxia in comparison to their non-asphyxiated controls.

Methodology: This is a prospective case - control study involving 54 asphyxiated term neonates and 54 non-asphyxiated term babies at LAUTECH teaching hospital, Osogbo. Serum levels of Sodium, Bicarbonate, Chloride, Calcium and Potassium were determined daily for 72 hours in both groups using standard methods. The results were compared.

Results: The overall prevalence of abnormal biochemical parameters namely hyponatraemia, hypocalcaemia, metabolic acidosis, hypochloraemia and hypokalaemia among the asphyxiated versus non-asphyxiated babies in the first 72 hours of life were $30.9 \%$ vs $19.8 \%(\mathrm{p}<0.020) ; 28.4 \%$ vs $4.9 \%$ (p $<$ $0.000) ; 30.9 \%$ vs $3.1 \%(\mathrm{p}<0.0001) ; 27.2 \%$ vs $25.9 \%(\mathrm{p}<0.200)$ and $24.7 \%$ vs $3.1 \%(\mathrm{p}<0.070)$ respectively.

Conclusion: Babies with hypoxic ischaemic encephalopathy stage III significantly showed the worst biochemical parameters; early estimation of serum electrolytes in neonates with perinatal asphyxia may be appropriate for timely intervention.
\end{abstract}

Keyword: Abnormal biochemical parameters, Nigeria, Perinatal Asphyxia.

*Corresponding Author

Kayode, O.V.

ORCID-NO: http://orcid.org/0000-0001-8338-4166.

Email:kayode.valentine@reddingtonlekki.com*

\footnotetext{
${ }^{1}$ Department of Paediatrics, Reddington Multi-Specialty Hospital, Victoria Island, Nigeria. ${ }^{2}$ Department of Paediatrics, College of Health Sciences, LAUTECH Osogbo, Nigeria.

${ }^{3}$ Department of Paediatrics, College of Health sciences, Obafemi Awolowo Teaching Hospitals Complex, Ile Ife, Nigeria.

${ }^{4}$ Department of Paediatrics, College of Health Sciences, Bowen University Teaching Hospital, Ogbomosho, Nigeria.
} 


\title{
Paramètres biochimiques anormaux entre les néo nés au terme avec asphyxie périnatale et leurs contrôles non asphyxiés dans Osogbo
}

\author{
*Kayode, O.V. ${ }^{1}$, Adebami, O.J. ${ }^{2}$, Oyedeji, O.A. ${ }^{2}$, Oninla, S. O. ${ }^{2}$, Oseni, S.B.A. ${ }^{3}$, \\ Odeyemi, A.O. ${ }^{4}$
}

\begin{abstract}
Résumé
Objectif de l'étude: Cette étude visait à déterminer la prévalence de paramètres biochimiques anormaux chez les nouveau-nés souffrant d'asphyxie périnatale par rapport à leurs témoins non asphyxiés.

Méthode de l'étude : Il s'agit d'une étude cas-témoins prospective portant sur 54 nouveau-nés à terme asphyxiés et 54 bébés à terme non asphyxiés à l'hôpital universitaire LAUTECH, Osogbo. Les taux sériques de sodium, de bicarbonate, de chlorure, de calcium et de potassium ont été déterminés quotidiennement pendant 72 heures dans les deux groupes en utilisant des méthodes standard. Les résultats ont été comparés.
\end{abstract}

Résultat de l'étude : La prévalence globale des paramètres biochimiques anormaux à savoir l'hyponatrémie, l'hypocalcémie, l'acidose métabolique, l'hypo chlorémie et l'hypokaliémie chez les bébés asphyxiés versus non asphyxiés au cours des 72 premières heures de vie était de $30,9 \%$ vs $19,8 \%$ (p $<0,020) ; 28,4 \%$ contre $4,9 \%$ (p $<0,000) ; 30,9 \%$ contre $3,1 \%$ (p $<0,0001) ; 27,2 \%$ vs $25,9 \%$ (p $<0,200$ ) et $24,7 \%$ vs $3,1 \%(p<0,070)$ respectivement.

Conclusion : Les bébés atteints d'encéphalopathie ischémique hypoxique de stade III ont montré de manière significative les pires paramètres biochimiques; une estimation précoce des électrolytes sériques chez les nouveau-nés souffrant d'asphyxie périnatale peut être appropriée pour une intervention rapide.

Mots-clés: Paramètres biochimiques anormaux, Nigéria, asphyxie périnatale

*Corresponding Author

Kayode, O.V.

ORCID-NO: http://orcid org/0000-0001-8338-4166

Email:kayode.valentine@reddingtonlekki.com*

\footnotetext{
'Department of Paediatrics, Reddington Multi-Specialty Hospital, Victoria Island, Nigeria.

${ }^{2}$ Department of Paediatrics, College of Health Sciences, LAUTECH Osogbo, Nigeria.

${ }^{3}$ Department of Paediatrics, College of Health sciences, Obafemi Awolowo Teaching Hospitals Complex, Ile Ife, Nigeria.

${ }^{4}$ Department of Paediatrics, College of Health Sciences, Bowen University Teaching Hospital, Ogbomosho, Nigeria.
} 


\section{INTRODUCTION}

Perinatal asphyxia is defined as failure to initiate and sustain breathing at birth subsequent to simultaneous occurrence of hypoxia and ischaemia which often manifests as acidosis and hypercapnoea. $(1,2)$ It is an important cause of neonatal morbidity and mortality. It accounts for $23 \%$ of 4 million neonatal deaths and $26 \%$ of 3.2 million stillbirths each year globally (3-5). The burden of asphyxia related neonatal deaths is therefore significantly more worrisome in lowand middle-income countries than in high income countries as perinatal asphyxia in the former contributes about $98-99 \%$ to global neonatal deaths $(3-8)$.

Furthermore, in perinatal asphyxia, multi - organ dysfunction occurs from the multi systemic effects of the asphyxia. This causes metabolic and biochemical changes with resultant derangement in the body electrolytes $(9$, 10). Sodium, Potassium and Calcium are the major electrolytes in the human body whose level must be maintained optimally for efficient physiological processes $(10,11)$. For example, serum Calcium acts as co-factor for several enzymatic activities and assist in optimal muscular functions when within normal limits $(10,11)$. Deviation of electrolytes from these normal levels can therefore result in various clinical abnormalities (11).

Excess or suboptimal level of electrolytes termed dyselectrolytaemia can occur in perinatal asphyxia due to accompanying energy - deprived ATPase pump dysfunction and possible renal compromise. This can manifest as jitteriness, convulsions, shock, hypotonia and rarely, coma; which may contribute to morbidity and mortality in neonates with perinatal asphyxia (10). It is therefore imperative to ascertain electrolytes status of asphyxiated neonates for proper clinical planning and timely intervention.

More importantly, Nigerian studies which serially compare electrolytes' status of asphyxiated and non-asphyxiated neonates, are scarce to the best of researchers' knowledge. In fact, prospective neonatal studies in Nigeria that evaluate any accompanying electrolytes' abnormalities known with perinatal asphyxia, on the outcome of the asphyxiated babies, are inadequate to the best of our reviews of literature (11-14). For instance, fewer Nigerian studies have noted abnormal biochemical and metabolic changes accompanying perinatal asphyxia, (1214) namely Onyiriuka in Benin City, demonstrated hypocalcemia among severely asphyxiated neonates (12) while Ogunfowora et al (14) in Sagamu, recorded metabolic acidosis and hypocalcaemia among babies with perinatal asphyxia. These two separate studies apart from being retrospective, did not consider other electrolytes besides serum calcium and serum bicarbonate.

This study was therefore undertaken to determine the prevalence of abnormal biochemical parameters among babies with perinatal asphyxia and their non- asphyxiated controls.

\section{MATERIALS AND METHODOLOGY}

This is a prospective case - control study which was conducted at the Special Care Baby Unit (SCBU) of Ladoke Akintola University of Technology [LAUTECH] Teaching Hospital, Osogbo, Osun state, Southwestern Nigeria; over a period of eight months (March 2017 to October 2017.) The SCBU receives 300 neonatal admissions annually (16). Ethical approval for the study was obtained from the Ethics and Research committee of LAUTECH Teaching Hospital, Osogbo, Osun State (LTH/EC/2016/05/272). Sixty neonates per group of asphyxiated babies and non-asphyxiated controls totaling a sample size of 120 neonates were recruited into the study, after taking the parental written and signed informed consents.

Neonates who had completed 37 weeks of intra uterine life are defined as having reached the term gestational age and were recruited consecutively into the study till the calculated sample size was attained. Term gestation was specifically determined by using estimated gestational age (EGA) derived from Mothers' Last Menstrual Period (LMP) using the Naegele's rule. However, Ballard scoring to determine EGA was used for mothers who did not know their LMP. Thus, term newborns from within 24 hours of birth whose documented Apgar score was less than 7 at 1 minute and or less than 7 at 5 -minutes were subsequently recruited as the asphyxiated cases, based on the World Health Organization (WHO) criteria.

Nonetheless, when Apgar score was not documented for hospital outborn deliveries, newborns with history of delayed cry at birth or features of unexplained neonatal encephalopathy [neonatal encephalopathy is defined as neonatal seizures or coma following delivery in the background of delayed cry at birth] were considered as asphyxiated. On the other hand, term Newborns of $<24$ hours of life with documented Apgar score of 7 and above at 1 minute were recruited as the healthy control 
groups.

Preterm neonates, infants of diabetic, hypertensive, pre - eclamptic or eclamptic mothers; neonates of mothers on chronic diuretic use and mothers with renal disease were excluded from the study. Infants whose mothers received general anaesthesia, opiates or sedatives prior to delivery were also excluded in order to prevent falsely low Apgar score record.

\section{Sample size determination}

In view of the comparative nature of this study, formula for calculating sample size $[\mathrm{N}]$ per group was used. (17)

$\mathrm{N}=\frac{\mathrm{r}+1}{\mathrm{r}} \frac{\left(\mathrm{P}^{*}\right) \mathrm{x}\left(1-\mathrm{P}^{*}\right) \mathrm{x}(\mathrm{Z} \beta+\mathrm{Z} \alpha)^{2}}{(\mathrm{P} 1-\mathrm{P} 2)^{2}}$

$\mathrm{N}=$ sample size per group [cases and controls] $r=$ Ratio of cases to control; equal ratio $=1: 1=1$ $\mathrm{P} 1=$ Prevalence of perinatal asphyxia in a previous study $=34.3 \%[0.343] \quad$ (16)

P2 = Prevalence of asphyxia among the control = $0 \%$ since the control should not have any features suggestive of asphyxia;

$\mathrm{P}^{*}=$ Average proportion exposed $=\frac{\mathrm{P} 1+\mathrm{P} 2}{2}$

$Z \beta=$ Power at $90 \%=1.96$

$\mathrm{Z} \alpha=$ power at $80 \%=0.84$.

The minimum sample size per group of neonates is $\approx 35$.

\section{Subject recruitment process, venesection and data collection.}

This involved taking parental informed consent, direct recruitment and active resuscitation of term newborns with features of perinatal asphyxia in the first 24 hours of life by the Paediatrician who has been well trained in neonatal resuscitation. General physical and systemic examinations of the asphyxiated babies including CNS examinations were done. Subsequently, features of perinatal asphyxia were graded based on the Sarnat and Sarnat staging for encephalopathy (18).

On the other hand, all the nonasphyxiated neonates were examined at similar time interval from within 24 hours of life through 72 hours as the control group. Anthropometry was also done for all the babies and all Clinical findings were documented in the study proforma. Neonates with asphyxia were managed promptly as per the unit protocol. Furthermore, blood samples of 2-ml each was collected using the dorsum of the hands or feet of the subjects into a Lithium heparin bottle. Three separate samples were collected within 24 hours of birth, at 48 hours and at 72 hours of life; using an open- ended
23 - G needle with standard sterile procedures. (12). All samples taken were sent to the laboratory within the study facility for processing within 30 minutes of collection. Sera of the subjects were then subjected to flame photometry to determine the serum Sodium, Chloride, Potassium, and Bicarbonate while serum Calcium was measured by enzymatic method using the 0-Cresolphthalein Complexone method by the laboratory scientist. The results of the electrolytes were also cross - checked by a Chemical pathologist.

Other information including the maternal and peripartal history, duration of hospital stay, and outcome of admission (defined as any of: discharged, discharged against medical advice, or death among the asphyxiated babies) were all entered into the study proforma. Instruments that were used in this study include a proforma; Bassinet weighing scale, nonstretchable measuring tape, infantometer, Urinalysis strip [Combi 9], paediatric stethoscope, Ambulatory mechanical breathing unit [AMBU] bag and flame photometer model 6420 (a laboratory based equipment).

\section{Statistical analysis}

The data was subsequently analysed using statistical package for social sciences (SPSS) version 21. Frequency distributions were displayed using tables and charts. Means and standard deviations were used to summarize the quantitative data. Comparison of categorical variables with tests of association was by chisquare $\left(x^{2}\right)$ test while multiple means were compared using the independent " $t$ " tests. Probability (p)-value of $<0.05$ was taken to be statistically significant.

\section{RESULTS}

Of the 60 newborns per group of the asphyxiated and non-asphyxiated neonates, only $54(95 \%)$ babies per group completed the present study. Twelve babies $(10 \%)$ were excluded because of incomplete data in 5 of them and 7 parents withdrew their babies from the study voluntarily. Of the 54 asphyxiated and 54 nonasphyxiated babies in the present study, there were 28 males $(51.2 \%)$ and 26 females (48.1\%) per each group giving a male to female ratio of 1.1 to 1 respectively.

Of the 54 mothers who had asphyxiated babies, 59.2\% mothers (32) were booked while the rest $-40.8 \%(22)$ were unbooked. In the control group, $96.3 \%$ (52) mothers were booked while the rest $3.7 \%$ (2) were unbooked patients. 
Other socio-demographic details as shown in Table 1.

In tables 2 and 3 , the means of serum Sodium, Potassium, Calcium, Bicarbonate and Chloride on day 1 , day 2 and day 3 of life were compared between the asphyxiated groups and the controls. Thus, the mean of serum Sodium and Potassium were significantly higher among the asphyxiated group when compared with the non-asphyxiated group. In addition, the Mean of serum calcium was lower in the asphyxiated group when compared with the non-asphyxiated group.

Furthermore, Figure I summarizes features of perinatal asphyxia in the asphyxiated babies which subsequently determined their Sarnat and Sarnat staging while figure II shows the severity of asphyxia in relation to the cases of abnormal biochemical parameters recorded.

\section{Prevalence of abnormal biochemical parameters among asphyxiated neonates compared to the non-asphyxiated controls.}

Except for hypochloraemia and hypokalaemia, other abnormal biochemical parameters were statistically different among babies with perinatal asphyxia compared to those without asphyxia. Hence, altogether over the 72 hour period, the prevalence of abnormal biochemical parameters namely hyponatraemia, hypocalcaemia, metabolic acidosis, hypochloraemia and hypokalaemia among the asphyxiated versus non asphyxiated babies in the first 72 hours of life were $30.9 \%$ vs $19.8 \%$ ( $<<$ 0.02 ); $28.4 \%$ vs $4.9 \%$ ( $<<0.000$ ); $30.8 \%$ vs $3.1 \%$ $(\mathrm{p}<0.0001) ; 27.2 \%$ vs $25.9 \%(\mathrm{p}<0.2)$ and $24.7 \%$ vs $3.1 \%(p<0.07)$ respectively. This is summarized in table 4 .

\section{Outcome of Babies with Perinatal Asphyxia and Significant Abnormal Biochemical Parameters.}

Of the 12 babies with severe perinatal asphyxia, 2 died with persistent hyponatraemia, hypocalcaemia and metabolic acidosis throughout the 3 days of serial electrolytes measurement. This is in contrast with occurrence of abnormal biochemical parameters in only 6 of the 10 babies who survived.

More importantly, there were more babies with abnormal biochemical parameters as the severity of asphyxia progresses from no encephalopathy to HIE III. Babies with HIE III had the longest hospital stay ( $24 \pm 6$ days) as shown (Table 5).

\section{DISCUSSION}

Newborns with perinatal asphyxia have abnormal biochemical parameters that can worsen their morbidity or even accelerate their mortality $(9-14,20-25)$. Suboptimal or excess electrolytes in the blood - dyselectrolytaemia among asphyxiated babies were demonstrated in the present study as abnormal biochemical parameters with higher prevalence documented in the asphyxiated babies than the non asphyxiated controls.

Studies which estimate all the serum electrolytes among asphyxiated babies in comparison to the non-asphyxiated ones in Nigeria are scarce to the best of our knowledge.(12) Most of the previous studies encountered (11 - 14, 24 - 26), estimated only one to three serum electrolytes, hence comparison of the present multi-electrolyte based study with the previous studies appears difficult.

Nevertheless, the overall prevalence of hypocalcaemia in this study is higher than the $22.6 \%$ recorded by Onyiriuka (12) in Benin City and $9.4 \%$ by Omene and Diejomaoh (25). The hypocalcaemia observed in the present study is however less than $80.6 \%$ noted by Ogunfowora $e t$ al (14) in Sagamu - south - western Nigeria. It is also lower than the $37.6 \%$ hypocalcaemia prevalence documented by Tsang et al $(12,26)$ in two separate studies.

One of the reasons for the observed differences in the prevalence of hypocalcaemia between this study and the earlier studies listed may be due to methodology employed in the various studies. In fact, the timing of sample collection and reference values used, also play a crucial role in estimation of serum electrolytes generally. For instance, total body calcium level falls in the first 24 to 48 hours of life, after which normal values are reverted to. $(12,25,26)$ Within the first 24 hours, the conventional reference value for calcium is $2.0-2.65 \mathrm{mmol} / 1(12,21,23)$. Beyond 24 hours of life, reference value for serum calcium becomes $1.75-3 \mathrm{mmol} / 1$ (21). Not taking this into consideration in reference to the local laboratory reference may over or under diagnose early hypocalcaemia especially in term infants. In the present study, prevalence of hypocalcaemia would increase by $20-30 \%$ if the first day reference value was applied throughout the 72 hours of life.

Moreover, Tsang et al (26) Speidel et al (28) and Rennie with Robertson (29) documented early onset hypocalcaemia in their studies. Apparently healthy neonates can have early hypocalcaemia in the first 24 hours due to abrupt 
caesation of placental supply of calcium following delivery $(28-30)$. This physiological nadir may be exacerbated into hypocalcaemic values in asphyxiated newborns. Although, it appears poorly understood, various explanations for hypocalcaemia in asphyxiated neonates have been offered namely delayed feeding, calcitonin release, target organ unresponsiveness, increased endogenous phosphate, functional hypoparathyroidism and intravenous bicarbonate use during resuscitation. (12, 25 - 28). Intravenous bicarbonate use during neonatal resuscitation has been known to cause movement of calcium from blood to the bone further causing hypocalcaemia (12). None of the neonates in this study had bicarbonate during resuscitation as it was not part of the unit protocol of management.

Similarly, serum level of bicarbonate was also reviewed by Ogunfowora et al (14) among the asphyxiated babies. Prevalence of metabolic acidosis was $58.5 \%$ found in that study. It is higher than that of the present study (30.8\%). Metabolic acidosis is a constant finding in most of the earlier studies $(9-11,27)$. Hypoxia in perinatal asphyxia usually drives the anaerobic pathway leading to accumulation of lactate and glutamate with resultant acidosis. It is better correlated with use of arterial blood gases. This could not be done in this study because of non-availability of the arterial blood gas device at the facility of study. Arterial blood gases were not done in any of the previous studies for similar reason to that of the present study. Nonetheless, low serum bicarbonate was associated with severe perinatal asphyxia than in the nonseverely asphyxiated babies.

Moreover, the present study documented higher prevalence of hyponatraemia than another south - west Nigerian study: Adebami et al (27) who noted hyponatraemia among 128 babies $(22.9 \%)$ of the 563 babies studied (27). The disparities noted in these previous Nigerian studies and the present one may be due to differences in methodologies, duration of study, time of study and differences in study designs. For example, in the retrospective study by Adebami et al (27)), only $66.9 \%$ (377 babies) of the 563 babies studied had their electrolytes checked. This limitation was also noted by Omene with Diejomaoh (25) in which serum calcium was evaluated among 226 asphyxiated babies during a retrospective study. They recorded a lower prevalence of serum calcium. Retrospective studies can be associated with missing data which may explain why some of the population studied by Omene with Diejomaoh did not have their serum calcium recorded (25).

Although frank hyperkalaemia does not occur in most of the previous studies $(9-11,15$, $20,24)$ the mean potassium in asphyxiated babies were usually higher. The reason for elevated serum potassium in asphyxiated babies compared to apparently healthy controls, has been linked to dysfunction of the energy dependent sodium potassium (ATPase) pump. This pump usually pushes out sodium extracellularly and pumps in potassium intracellularly. The loss of the pump function leads to fall in extracellular sodium (hyponatraemia) and rise of extracellular potassium (apparent hyperkalaemia) $(10,11)$. Also, acute renal failure resulting from multi organ dysfunction effects of asphyxia can lead to worsening serum potassium culminating into hyperkalemia. $(19,20)$.

Beyond Nigeria, two Indian studies namely Basu et al (10) and Jayaprakash with Murali (9) demonstrated hyponatraemia, hypocalcaemia and higher mean potassium in the asphyxiated neonates compared to the non asphyxiated group. For Basu et al (10), the means of serum sodium and potassium in each group with respect to asphyxiated and nonasphyxiated neonates were $122.1 \pm 6.0 \mathrm{vs} 138.8 \pm$ $2.7 \mathrm{mmol} / 1$ and $5.05 \pm 0.63 \mathrm{vs} 4.19 \pm 0.40 \mathrm{mmol} / 1$ respectively.

This is fairly comparable to the overall means of sodium and potassium with respect to asphyxiated and non-asphyxiated babies in the present study. This is also true for Jayaprakash and Murali (9).

More importantly, hyponatraemia was found more among the moderate to severely asphyxiated newborn compared to the mildly asphyxiated babies in the present study. It was a constant finding in the two deaths recorded. This is similar to the findings by Adebami et al (27); Joag et al (11) and Jayaprakash with Murali (9) where hyponatraemia was found more among asphyxiated neonates with severe encephalopathy than other asphyxiated neonates with mild or no encephalopathy. Hyponatraemia therefore, remains a cause for concern in asphyxiated babies as it can lead to cerebral oedema and is also a component of syndrome of inappropriate anti - diuretic hormone (SIADH). The fall in plasma osmolality in hyponatraemia often causes shift in fluid movement into the neuronal cells leading to cerebral oedema. Cerebral oedema has been known to increase mortality in babies with perinatal asphyxia (19, 20).

However, the mortality of $3.7 \%$ 
among the asphyxiated neonates in this study is less than the mortalities recorded in earlier studies $(9-18,24-26)$. This is probably because the results of abnormal biochemical parameters in the present study were retrieved within 24 - 48 hours of estimation. This made interventions in form of correcting the electrolyte abnormalities possible. Hypocalcaemia and metabolic acidosis found in the present study were corrected as per unit protocol. This may be unpredictable in retrospective studies which form most of the earlier findings. Perhaps, the larger sample size in earlier studies is responsible for such differences also. Nonetheless, abnormal biochemical parameters do occur in neonates with perinatal asphyxia and correlate positively with severity of asphyxia. Hypocalcaemia and metabolic acidosis were the most consistent findings even at 72 hours of life.

\section{CONCLUSION}

Abnormal biochemical parameters namely hyponatraemia, hypocalcaemia and metabolic acidosis occurred in this study on the average of $30.9 \%, 28.4 \%$ and $30.8 \%$ respectively among babies with perinatal asphyxia in the first 72 hours of life. Also, of babies without perinatal asphyxia, 19.8\% had hyponatraemia, 4.9\% had hypocalcaemia and $3.1 \%$ had metabolic acidosis. Thus, abnormal biochemical parameters occurred significantly more in the asphyxiated babies compared to the non-asphyxiated babies.

Finally, hyponatraemia, hypocalcaemia and metabolic acidosis were constant findings among the severely asphyxiated babies who died and those who were on prolonged hospital admission.

\section{Conflict of interests: None.}

Acknowledgements: The Authors are grateful to the following people for their assistance during the period of study: $\mathrm{Mr}$ Raheem GO of the Chemical pathology department, LTH Osogbo; The Staff and Nurses of the SCBU and the Labour Ward, LTH, Osogbo.

\section{REFERENCES}

1. World Health Organization [WHO]. Basic newborn resuscitation: A practical guide. WHO, Geneva, 1997.

2. Adams - Chapman I, Still B J. Nervous system disorders - hypoxia - ischaemia. In: Kliegmann RM, Berhrman RE, Jenson HB, Stanton BF, (eds). Nelson textbook of Paediatrics. 18th edition. Saunders Philadelphia, USA. 2007; 718 -720 .
3. Lawn JE, Cousens S, Zupan J. 4 million neonatal deaths:When $x$ Wherex Whyx Lancet 2005; 365 (9462): $891-900$.

4. Unisex. State of the world's children 2009. UNICEF 2009: New York.

5. Lawn JE, Wilczynka - Ketende K, Cousens SN. Estimating the causes of 4 million neonatal deaths in the year 2000. Int J Epidemiol 2006; 35 (3): 706-718

6. Stanton C, Lawn JE, Rahaman H, Wilczynska Ketende K, Hill k. Still birth rates: delivering estimates in 190 countries. Lancet 2006; 367(9521): 1487 - 1494.

7. Darmstadt GL, Bhutta ZA, Cousens S, Adam TW, De Bernis L. Evidence - based, cost effective interventions: how many newborn babies can we save $^{\chi}$ Lancet 2005;365 (9463): $977-988$.

8. Stoll BJ. The global impact of neonatal infection. Clin Perinatol 1997; 24(1): 1-21.

9. Jayaprakash K, Murah BH. Study of electrolytes status, glucose and uric acid levels in Perinatal Asphyxia. J evolution of med dent sc 2014; 3(18): 4786-4790.

10. Basu P, Som S, Das H, Choudhun N. Electrolytes status in birth asphyxia. Indian J Pediatr 2010; 77(3): 259-262.

11. Joag G, Langade R, Aundhakar H, Raghav K. Study of serum sodium, serum glucose and blood glucose in neonates with perinatal asphyxia. Inter J Multi 2017; 4(2): $82-84$.

12. Onyiriuka AN. Prevalence of neonatal hypocalcaemia among full term infants with severe perinatal asphyxia. Pacific J Med Sci 2011; 8(1):2072 - 1625 .

13. Padayachee N, Ballot DE. Outcomes of neonates with perinatal asphyxia at a tertiary academic hospital in Johannesburg, South Africa. S Afr J CH 2013; 7(3): 89-94.

14. Ogunfowora OB, Ogunlesi TA, Fetuga MB, Oyinlade OA. Clinical manifestations and outcome of hospitalized babies with birth asphyxia in Sagamu. Nig J Paed 2008; 35: 12 18.

15. Onyearugha CN, Ugboma HA. Severe birth asphyxia: Risk factors as seen in a tertiary institution in the Niger Delta area of Nigeria. Control J Trop Med 2010; 4: 11 - 19.

16. Adebami OJ. Pattern of neonatal seizures in Osogbo, South - western Nigeria. S Afr J Cli Hlth 2010; 4(2): 46-49.

17. Charen J, Biswas T. How to calculate sample size for different study designs in medical research. Indian J Psy Med 2013; 35(2):121-126.

18. Sarnat HB, Sarnat MS. Neonatal encephalopathy following fetal distress. A clinical and electroencephalographic study. Arch Neurol 1976; 33(10): 696-705.

19. Adedoyin OT, Akindele JA, Ajayi A, Okesina AB. Serum electrolytes, urea and creatinine in clinically stable newborn. West Afr J Med, 2001; 20(3): $263-7$.

20. Ray B, Gobinda M. Study of renal profile in 
Babies with Perinatal asphyxia in a tertiary care hospital. J Nepal Paediatr 2013; 206-212.

21. Stanley FL. Reference values for laboratory tests and procedures In: Kliegmann RM, Berhrman RE, Jenson HB, Stanton BF, (eds). Nelson textbook of Paediatrics. 20th edition. Saunders Philadelphia, USA. 2007; 5305-5315.

22. Ornella Lincetto. World Health Organization [WHO] Protocol. Summary of the previous meeting and protocol review. WHO, Geneva, 2007.

23. Greenbaum LA. Electrolytes and acid base balance. In: Kliegmann RM, Berhrman RE, Jenson HB, Stanton BF, (eds). Nelson textbook of Paediatrics. 18th edition. Saunders Philadelphia, USA. 2007; 267-308.

24. Masood N, Muntiha S, Sharif M, Asghar RM. Correlation of serum electrolyte changes with severity of birth asphyxia in newborns. JRMC; 2016;20(1): 27-29.

25. Omene JA, Diejomaoh FME. Analysis of 226 asphyxiated newborn infants at the University of Benin Teaching Hospital, Benin City. Nig J Paediatr.1978; 25-29.

26. Tsang RC, Oh W. Neonatal hypocalcaemia in low birth weight infants. Pediatrics 1970; 45: 773 781.

27. Adebami JO, Joel - Medewase IV, Oyedeji GA. Clinico laboratory determinants of outcome among babies with perinatal asphyxia in Osogbo, South - Western Nigeria. Int Contemp Pediatr 2016; 3: 409415.

28. Speidel B. Fleming P, Henderson J, Leaf A, Marlow N, Russel G et al. A neonatal Vade Mecum. 3rd edn. London, Arnold publishers Limited, 1998; 282-283.

29. Rennie JM, Robertson NRC. A manual of Neonatal intensive care 4th edn, London Arnold publishers Limited, 2002; $28-32$.

30. Minouni F, Tsang RC. Neonatal hypocalcaemia: To treat or not to treatx Am Coll Nutr 1994; 13: $408-415$.

How to cite this article:

Kayode, O.V., Adebami, O.J., Oyedeji, O.A., Oninla, S. O., Oseni, S.B.A., Odeyemi, A.O. Abnormal biochemical parameters among term neonates with perinatal asphyxia and their non-asphyxiated controls in Osogbo. Research Journal of Health Sciences, 2021, 9(3): 308-319 
Table 1: Socio-demographic characteristics of the neonates

\begin{tabular}{lll}
\hline Variables & $\begin{array}{l}\text { Asphyxiated } \\
\mathbf{5} \mathbf{5 4}(\mathbf{\%})\end{array}$ & $\begin{array}{l}\mathbf{n} \text { No Asphyxia n } \\
\mathbf{5 4} \mathbf{( \% )}\end{array}$ \\
\hline Age on Admission (hours) & & \\
& & $54(100)$ \\
$0-8$ & $15(27.8)$ & $0(0.00)$ \\
$>8-16$ & $13(24.1)$ & $0(0.00)$ \\
$>16-=24$ & $26(48.1)$ & \\
& & $26(48.1)$ \\
Gender & & $28(51.9)$ \\
Female & $26(48.1)$ & \\
Male & $28(51.9)$ & $10(18.5)$ \\
Birth weight (kg) & & $24(44.4)$ \\
$2.10-2.5$ & $10(18.5)$ & $20(37.1)$ \\
$>2.50-3.0$ & $24(44.4)$ & \\
$>3.00-4.0$ & $20(37.1)$ & \\
\hline
\end{tabular}

Table 2: Serial Means of Serum Sodium, Potassium and Calcium among the asphyxiated and nonasphyxiated babies at day 1,2 and 3 .

\begin{tabular}{|c|c|c|c|c|c|c|}
\hline $\begin{array}{l}\text { Means of serum } \\
\text { Electrolyte } \\
\text { [Mmol/l] }\end{array}$ & Day 1 (SD) & $\begin{array}{l}F-\text { value } \\
(p-\text { value })\end{array}$ & Day 2 (SD) & $\begin{array}{l}F \text { - value } \\
\text { (p-value) }\end{array}$ & Day3 (SD) & $\begin{array}{l}F \text { - value } \\
\text { (p- value) }\end{array}$ \\
\hline \multicolumn{7}{|l|}{ Serum Sodium } \\
\hline \multicolumn{7}{|l|}{ Asphyxia } \\
\hline Present (54) & $132.30(5.1)$ & 6.072 & $131.30(4.5)$ & 0.371 & $131.90(6.1)$ & 7.761 \\
\hline Absent (54) & $130.25(4.0)$ & $(0.015)^{*}$ & $131.70(3.7)$ & $(0.544)$ & $131.70(4.2)$ & $(0.844)$ \\
\hline Overall mean & $131.30(4.7)$ & & $131.50(4.1)$ & & $131.80(5.2)$ & \\
\hline \multicolumn{7}{|l|}{ Serum Potassium } \\
\hline \multicolumn{7}{|l|}{ Asphyxia } \\
\hline Present (54) & $4.27(0.89)$ & 17.717 & $4.12(0.70)$ & 12.245 & $4.20(0.56)$ & 2.559 \\
\hline Absent (54) & $3.73(0.43)$ & $(0.000)^{*}$ & $3.66(0.41)$ & $(0.000)^{*}$ & $3.65(0.59)$ & $(0.000)^{*}$ \\
\hline Overall mean & $3.99(0.74)$ & & $3.89(0.61)$ & & $3.92(0.63)$ & \\
\hline \multicolumn{7}{|l|}{ Serum Calcium } \\
\hline \multicolumn{7}{|l|}{ Asphyxia } \\
\hline Present (54) & $2.08(0.20)$ & 1.126 & $2.01(0.15)$ & 1.063 & $2.02(0.15)$ & 0.048 \\
\hline Absent (54) & $2.09(0.19)$ & $(0.867)$ & $2.12(0.18)$ & $(0.000)^{*}$ & $2.13(0.18)$ & $(0.000)^{*}$ \\
\hline Overall mean & $2.09(0.21)$ & & $2.07(0.18)$ & & $2.12(0.16)$ & \\
\hline
\end{tabular}

$* \mathrm{P}<0.05=$ significant 
Table 3: Serial Means of Serum Chloride and Bicarbonate among the asphyxiated and non-asphyxiated babies at day 1,2 and 3 .

\begin{tabular}{|c|c|c|c|c|c|c|}
\hline $\begin{array}{l}\text { Means of serum } \\
\text { Electrolyte } \\
\text { [Mmol/l] }\end{array}$ & Day 1 (SD) & $\begin{array}{l}\mathbf{F} \text { - value } \\
(\mathbf{p}-\text { value })\end{array}$ & Day 2 (SD) & $\begin{array}{l}F-\text { value } \\
(p-\text { value })\end{array}$ & Day3 (SD) & $\begin{array}{l}F-\text { value } \\
(p-\text { value })\end{array}$ \\
\hline $\begin{array}{l}\text { Serum Chloride } \\
\text { Asphyxia }\end{array}$ & & & & & & \\
\hline Present (54) & $95.70(13.79)$ & & $97.70(4.10)$ & & $99.41(3.89)$ & \\
\hline Absent (54) & $98.03(4.38)$ & 3.531 & $98.60(3.29)$ & 3.401 & $95.06(13.51)$ & 3.004 \\
\hline Overall Mean & $96.87(10.24)$ & $(0.122)$ & $98.18(3.73)$ & $(0.217)$ & $97.23(10.13)$ & $(0.019)^{*}$ \\
\hline $\begin{array}{l}\text { Mean Serum } \\
\text { Bicarbonate } \\
\text { Asphyxia }\end{array}$ & & & & & & \\
\hline Present (54) & $21.70(10.28)$ & & $21.22(2.33)$ & & $20.48(4.30)$ & \\
\hline Absent (54) & $21.19(1.40)$ & 5.763 & $22.29(1.31)$ & 12.686 & $22.85(2.07)$ & 0.934 \\
\hline Overall Mean & $21.44(7.38)$ & $(0.324)$ & $21.76(1.96)$ & $(0.004)^{*}$ & $21.67(3.56)$ & $(0.000)^{*}$ \\
\hline
\end{tabular}

$* \mathbf{p}<0.05$ significant.

Table 4: Prevalence of abnormal biochemical parameters among asphyxiated babies and their non asphyxiated controls.

\begin{tabular}{|c|c|c|c|c|}
\hline $\begin{array}{l}\text { Abnormal } \\
\text { Biochemical } \\
\text { Parameters }\end{array}$ & $\begin{array}{l}\text { No of Cases: Day } 1 \\
\text { N=54 (\%) }\end{array}$ & $\begin{array}{l}\text { No of Cases: Day } 2 \\
N=54(\%)\end{array}$ & $\begin{array}{l}\text { No of Cases: Day } 3 \\
N=54(\%)\end{array}$ & $\begin{array}{l}\text { Overall } \\
\text { Prevalence } \\
(\%)\end{array}$ \\
\hline \multicolumn{5}{|l|}{ Asphyxia } \\
\hline Hyponatraemia & $22(40.7)$ & $18(33.3)$ & $10(18.5)$ & $50(30.9)^{*}$ \\
\hline Hypokalaemia & $23(42.5)$ & $13(24.1)$ & $4(7.4)$ & $40(24.7)^{x}$ \\
\hline Hypocalcaemia & $10(18.5)$ & $6(11.1)$ & $30(55.6)$ & $46(28.4)^{*}$ \\
\hline Metabolic acidosis & $23(42.6)$ & $13(24.1)$ & $14(25.9)$ & $50(30.9)^{*}$ \\
\hline Hypochloraemia & $18(33.3)$ & $18(33.3)$ & $8(14.8)$ & $44(27.2)^{x}$ \\
\hline \multicolumn{5}{|l|}{ No Asphyxia } \\
\hline Hyponatraemia & $8(14.8)$ & $18(33.3)$ & $6(11.1)$ & $32(19.8)^{*}$ \\
\hline Hypokalaemia & $4(7.4)$ & $1(1.9)$ & $0(0.0)$ & $5(3.1)^{x}$ \\
\hline Hypocalcaemia & $2(3.7)$ & $6(11.1)$ & $0(0.0)$ & $8(4.9)^{*}$ \\
\hline Metabolic acidosis & $4(7.4)$ & $1(1.9)$ & $0(0.0)$ & $5(3.1)^{*}$ \\
\hline Hypochloraemia & $16(29.6)$ & $6(11.1)$ & $20(37.0)$ & $42(25.9)^{x}$ \\
\hline
\end{tabular}

* Significant $\mathrm{p}$ - values for hyponatraemia, hypocalcaemia and metabolic acidosis: $30.9 \%$ vs $19.8 \%(\mathrm{p}<0.02)$; $28.4 \%$ vs $4.9 \%(\mathrm{p}<0.000) ; 30.8 \%$ vs $3.1 \%(\mathrm{p}<0.0001)$ among asphyxiated than the non - asphyxiated babies respectively.

${ }^{*}$ Abnormalities of serum potassium and chloride: not significant and not associated with severity of perinatal asphyxia. 
Table 5: Outcome of Babies with Perinatal Asphyxia and significant Abnormal Biochemical Parameters.

\begin{tabular}{lcllc}
\hline $\begin{array}{l}\text { Severity of } \\
\text { Asphyxia }\end{array}$ & $\begin{array}{l}\text { Frequency } \\
\text { of cases }\end{array}$ & $\begin{array}{l}\text { Cases with } \\
\text { Abnormal } \\
\text { Biochemical } \\
\text { parameters n (\%) }\end{array}$ & $\begin{array}{l}\text { Mean(SD) of } \\
\text { Hospital stay in } \\
\text { Days }\end{array}$ & Mortality \%(n) \\
\hline No HIE & 12 & $6(50.0)$ & $5 \pm 2$ & $0.0(0)$ \\
HIE I & 6 & $4(66.6)$ & $9 \pm 3$ & $0.0(0)$ \\
HIE II & 24 & $14(58.3)$ & $17 \pm 0$ & $0.0(0)$ \\
HIEIII & 12 & $8(66.7)$ & $24 \pm 6$ & $16.7(2)$ \\
Total & 54 & $32(59.2)$ & $14 \pm 3$ & $3.7(2)$ \\
& & $p<0.0000^{*}$ & & \\
\hline
\end{tabular}

$* \mathrm{p}$ significant at $<0.05 ; \mathrm{df}=9 ; \chi^{2}=41.47$

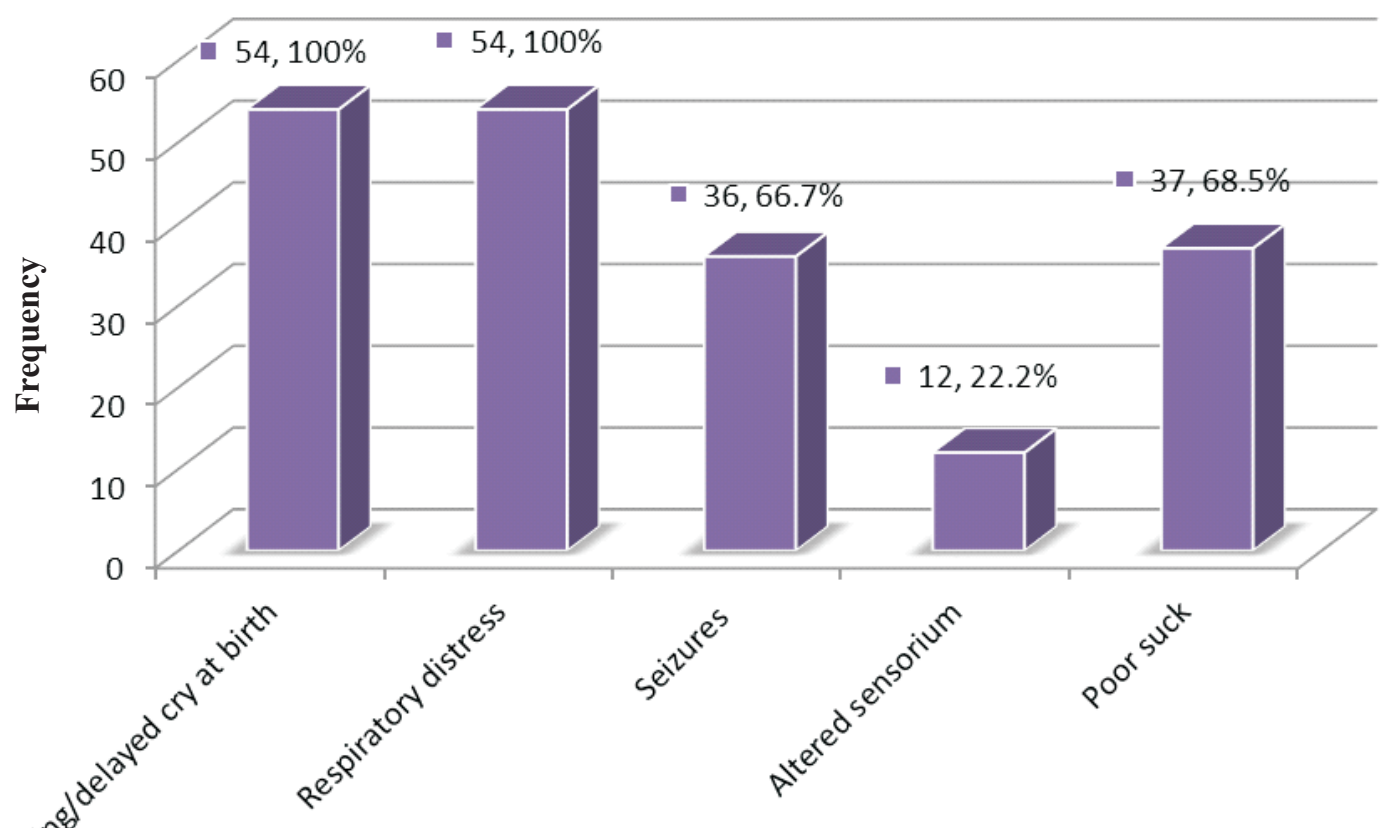

Severity of asphyxia

Figure 1: Features* of Perinatal asphyxia found among the asphyxiated neonates.

* Some babies have more than one features of perinatal asphyxia 


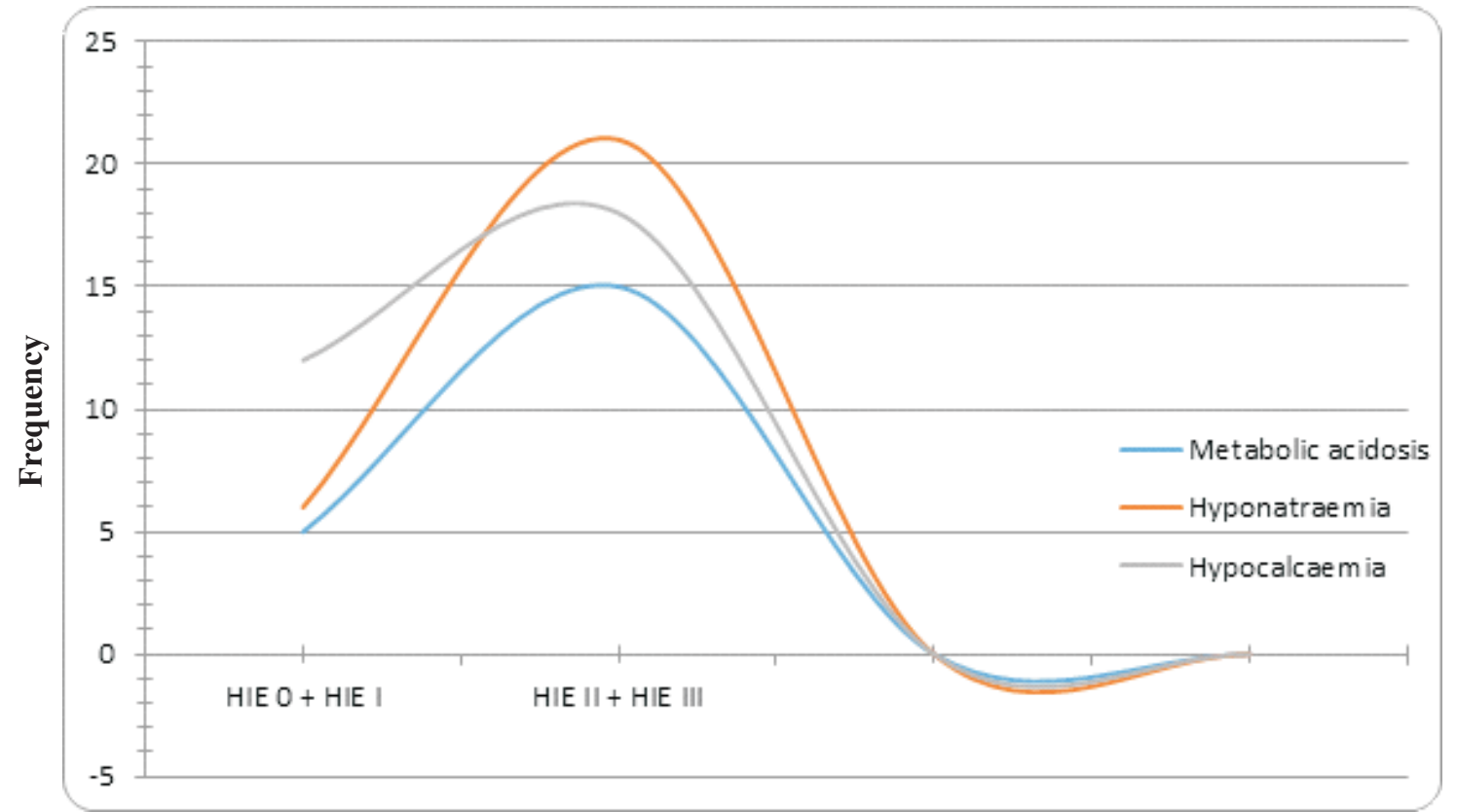

Figure 2: Association between Severity of perinatal asphyxia and level of abnormal biochemical parameters.

Key: $\quad$ HIE 0 = No features of hypoxic ischaemic encephalopathy;

HIE I = Hypoxic ischaemic encephalopathy stage I;

HIE II = Hypoxic ischaemic encephalopathy stage II;

HIE III = Hypoxic ischaemic encephalopathy stage III. 